\title{
KASUS KEWARISAN ISTIMEWA GHARAWAIN DITENGAH ISU KEADILAN GENDER
}

\author{
Wahidah \\ Universitas Islam Negeri Antasari Banjarmasin \\ Email: wahidah.antasari@gmail.com
}

\begin{abstract}
Cases of special inheritance, characterized by the structure of the heirs are standard, and there are deviations from the science of inheritance (faraidh). Operational method of calculation, making the mother "deceived" in two cases. In the midst of issues of gender justice, according to profession, expertise and perspective, society responds to it remains in diversity but is highly adaptive. From any point of view, ijtihadiyah products in the past dozens of centuries, can be felt and understood the wisdom related to maqashid al syariah. But it is not an exaggeration if the part of tsuluts al baqi (one-third of the rest) that is the privilege of Gharawain's case should not be used as a provision of settlement in positive law in Indonesia.
\end{abstract}

Kata Kunci: Special Inherition, Gharawain, Ashobah, Third Remaining, Gender Issues

\section{Abstrak}

Kasus kewarisan istimewa/khusus, ditandai oleh struktur ahli warisnya yang bersifat baku, dan ada penyimpangan dari faraidh. Operasional metode perhitungannya, menjadikan ibu "tertipu" dalam dua kasusnya. Di tengah isu keadilan gender, sesuai profesi, keahlian dan perspektif, masyarakat meresponnya tetap dalam keragaman namun sangat adaptif. Dari sudut pandang manapun, produk ijtihadiyah di belasan abad yang silam ini, dapat dirasakan dan dipahami hikmahnya terkait maqashid al syariah. Namun tidak berlebihan jika bagian tsuluts al baqi (sepertiga sisa) yang menjadi keistimewaan kasus Gharawain tersebuthendaknya tidak dijadikan sebagai ketentuan penyelesaian dalam hukum positif di Indonesia.

Keywords: Kewarisan Istimewa, Gharawain, Ashobah, Sepertiga Sisa, Isu Gender

\section{Pendahuluan}

Sesuai dengan hadits maka pembagian harta warisan dimulai dengan memberikan hak waris kepada ashhabul furudh, baru kemudian kepada ahli waris ashobah yang bagiannya tidak tentu banyak atau sedikitnya. Mereka bisa mendapat semuanya, atau lebih sedikit, atau bahkan tidak mendapat apa-apa, lantaran sudah habis (dikeluarkan) untuk ahli waris dzawil furudh(Pusvita, 2018). Ahli waris penerima sisa atas nama dirinya sendiri, dalam ilmu faraidh dikenal dengan istilahAshobah bi al Nafsi.

Konteksnya dengan Ashobah ini, dua tanda yang menjadi kekhususan pada kasus istimewa ini, oleh sebagian pendapat terkadang dinilai sebagai sesuatu yang justru tidak adil gender.Karena penyimpangan penyelesaian pembagian warisan dari faraidh itu, pada kenyataannya justru lebih menguntungkan kepada pihak lakilaki(Fahmi, 2018). Meskipun di sisi lain pendapat tersebut seharusnya masih diikuti dengan telaah mendalam terkait latar belakang kasusnya secara utuh, termasuk berbagai aspek dan perspektif lainnya. 
Pada kasus Gharawain, keistimewaan itu terdapat pada adanya (semacam) upaya untuk menjadikan ayah sebagai laki-laki mendapat bagian dua kali lipat daripada perempuan, yaitu ibu pewaris. Padahal kasus kewarisan tersebut, jika diselesaikan sesuai tuntunan faraidh, hasilnya justru sebaliknya, ibu mendapat dua kali lipat daripada bagian ayah, terutama dalam satu kasus yang struktur ahli warisnya terdiri dari suami, ibu, dan ayah pewaris(Anwar, 1981).

Kenyataan hasil penyelesaian seperti ini oleh sang penggagas ide utamanya,kemudian dicarikan jalan keluar tentang bagaimana caranya konsep al Qur'an "li al dzakari mitslu hazh al untsayain" bisa diterapkan dalam dua kasus yang strukturnya terdiri dari: Suami, ibu, dan ayah, atau istri, ibu dan ayah(Mubarak, n.d., p. 11). ${ }^{1}$ Tegasnya gharawain ini adalah kasus kewarisan seseorang yang meninggal dunia, dan ia meninggalkan pasangannya (suami/istri), bersama dengan kedua orang tua (ibu dan bapa) pewaris.

Begitu kuatnya perbedaan jenis kelamin, dan pada gilirannya mempengaruhi kepada hak/perolehan ahli waris laki-laki dan perempuan yang berbeda gender ini, tentunya menarik untuk ditelaah secara komprehensif, sambil menghubungkannya dengan respon masyarakat dan berbagai perspektif terkait penyelesaian kasusnya. Karena masih banyak masyarakat muslim yang tidak mengetahui tentang adanya penyelesaian pembagianwarisan secara khusus/istimewaini, yang terkadang justru akan menguntungkan atau bahkan merugikan hak warismereka karena berkurangnya bagian yang akan diterima oleh sebab pertimbangan keadilan gender.

Memang diakui bahwa persoalan waris mewarisi dalam Islam ini sangat identik dengan masalah (persoalan)gender. Tuduhan ketimpangan atau ketidakadilan pun senantiasa dimunculkan terkait perbedaan hak waris antara lakilaki dan perempuan. Apalagi dengan adanya penyelesaian kasus kewarisan istimewa ini, alam pikiran kita dianggap telah mundur ke belasan abad yang silam, utamanya dalam konteks telah diadopsinya istilah "sepertiga sisa" dalam salah satu pasal Kompilasi Hukum Islam (KHI) di Indonesia, pada buku II tentang Hukum Kewarisan(Muadz, 1994).

Oleh karena itu, maka pertanyaan yang muncul selanjutnya adalah, apakah ijtihad yang selama ini sudah menjadi ijma ulama, dan pada kenyataannya telah melawan prinsip kesetaraan/keadilan di tengah isugenderseperti sekarang ini, bisa saja untuk diabaikan?. Ataukah ia hanya merupakan sebuah alternatif (pilihan) yang tidak mengikat bagi ahli waris untuk menyelesaikan kasus kewarisan tersebut menurut cara-cara faraidhyang telah dipahami selama ini. ${ }^{2}$

\footnotetext{
${ }^{1}$ Sesuai dengan namanya Gharawain (bentuk tatsniyah, ganda), maka struktur ini adalah satu kasus lainnya. Pada kasus ini, ayah memang mendapat bagian lebih banyak daripada ibu, tetapi tidak sampai dua kali lipatnya. Kemudian diistimewakan untuk mendapat dua kali lipat dengan cara mengkhususkan kepada bagian ibu, yaitu dengan memberikan bagian $1 / 3$ sisa (tsuluts al baaqi).

2Meskipun ijtihad/ijma' juga menjadi bagian sumber hukum kewarisan, tetapi argumentasi bahwa ijtihad baru menjadi dalil hukum ketika permasalahan dan penyelesaian hukumnya tidak ditemui dalam al Qur'an atau hadits, maka wajar saja jika kemudian orang menolak menggunakan ijtihadyang sesungguhnya masih berkorelasi dengan prinsip dan aturan faraidh juga.
}

ADHKI: Journal of Islamic Family Law 
Di tengah isu keadilan gender, kasus-kasus kewarisan istimewa ini menarik untuk diperbincangkan. Karena boleh jadi masyarakat tidak banyak yang mengetahui bahwa ada solusi penyelesaian kasus waris yang terkesan "mengunggulkan laki-laki," sedangkan secara faraidh penyelesaiannya sudah mengisyaratkan pada kesetaraan gender. Jika ini yang sudah dirasakan oleh masyarakat, maka tidak heran jika kemudian ada tuduhan bahwa kewarisan Islam faraidh itu bercorak patrilineal. $^{3}$

Pembahasan masalah kewarisan Islam dalam perspektif gender, biasanya lebih banyak mengarah kepada pertanyaan umum yang sering dilontarkan, yaitu: Mengapa bagian perempuan itu hanya separo dari bagian laki-laki,? sehingga beberapa keadaan ketidaksamaan hak atau perolehan ahli waris yang berbeda gender ini, senantiasa dillustrasikan dengan pasangan anak perempuan dan anak laki-laki saja. Padahal untuk kasus kewarisan istimewa seperti gharawain ini, pasangan gender (ibu dan ayah pewaris) menunjukkan kenyataan, bahwa laki-laki itu tidak selalu mendapat bagian dua kali lipat dari perempuan, tetapi justru akan terbalik.

Oleh karena itu, penelitian mengenai kasus kewarisan istimewa gharawain ini menjadi urgen untuk memberikan verifikasi tentang kebenaran anggapan/pemahaman tersebut.Memang sudah banyak tulisan atau penelitian yang menyoroti tentang masalah "dua banding satu" untuk ahli waris laki-laki dan perempuan ini, namun selalu saja hasil analisisnya membuktikan kalau formulasi pembagian dengan pola (2:1) itu justru tidak melawan prinsip keadilan dalam kemitraannya(Basyir, n.d.). Atau selalu fokus pada upaya pembuktian tentang "tidak benar" adanya ketimpangan atau ketidakadilan dalam konsep hukum waris Islam faraidh.

Sampai saat ini, Indonesia masih belum memiliki unifikasi undang-undang pada bidang kewarisan. Kompilasi Hukum Islam (KHI) sendiri dalam statusnya yang lahir berdasarkan Instruksi Presiden (Inpres), oleh sebagian kalangan tidak dianggap sebagai hukum yang bersifat mengikat, walaupun ada upaya penyeragaman bagi seluruh Peradilan Agama di Indonesia untuk menjadikannya sebagai pedoman penyelesaian hukum keluarga, salah satunya adalah tentang masalahkewarisan.

Konteksnya dengan kasus istimewa/khusus ini, secara eksplisit hanya ada satu ketentuan dalam Kompilasi Hukum Islam (KHI), yaitu dengan diadopsinya istilah sepertiga sisa dalam aturan kewarisannya, dan itupun menurut penulis masih bersifat musykil.Selain tuduhan Farid Muadz di atas, maka adalah wajar (mungkin), jika secara implisit persoalan keistimewaan kasus-kasus lainnya pun tidak diatur.

${ }^{3}$ Meskipun demikian Hazairin telah meyakinkan dengan "keimanannya" bahwa kewarisan Islam itu sifatnya Bilateral. Lihat Bukunya tentang Hukum Kewarisan Bilateral Menurut Qur'an dan Hadith, P.T.Tintamas Indonesia, Jakarta, hal.1., (Bagian Pendahuluan). 
Ulama sebagai tokoh dan sosok panutan di masyarakat muslim, pendapatnya tidak jarang menjadi rujukan untuk orang menyelesaikan permasalahan kasus kewarisan, tidak terkecuali pada kasus-kasus kewarisan istimewa/khusus ini. Untuk itu pendapat mereka menjadi urgen untuk diketahui terkait pemahaman isu-isu keadilan gender di masyarakat. Apalagi kontribusi pemikiran mereka menjadi bukti nyata kehadiran Kompilasi Hukum Islam (KHI) di Indonesia.

Berdasarkan latar belakang tersebut; ulama, pimpinan pondok pesantren,guru/ustadz faraidh,akademisi, praktisi hukum (hakim), psikolog, atau sosiolog, patut diketahui pendapatnya terkaitisu keadilan gender saat ini, yang dihubungkan dengan penyelesaian kasus kewarisan istimewa gharawain. Mereka ini sangat cocok/relevan untuk dijadikan sebagai sumber data dalam konteks penelitian. Karena dari mereka ini pula, terkadang ketetapan "hukum" itu akan diperoleh.

Sama-sama sebagai bagian dari produk hukum faraidh, maka analisis keadilan gender dalam berbagai aspek adalah menjadi suatu keniscayaan terkait penyelesaian kasus kewarisan istimewagharawain ini.Ini mutlak diperlukan untuk menghasilkan suatu simpulan yang dapat memuaskan semua pihak(keluarga/ahliwaris) yang ada dalam struktur kasus bakunya, dengan tetap berpegang pada kaidah dan prinsipfaraidh yang diyakini kebenarannya, karena bersumber dari Musyarri'Yang Maha Adil dan Maha Bijaksana, sebagaimana disebutkan dalam ayat-ayat kewarisan-Nya.

Atas dasar ini, maka yang menjadi rumusan masalah dalam tulisan ini, adalah:

1. Bagaimana penyelesaian kasus kewarisan istimewa Gharawain menurut hukum waris Islam faraidh?

2. Bagaimana tanggapan (pendapat) masyarakat tentang keadilan gender dalam penyelesaian kasus kewarisan istimewaGharawain?

\section{Hasil dan Pembahasan}

Kasus kewarisan Gharawain atau disebut juga dengan al 'Umariah. Jumhur fukaha mengungkapkannya dengan masalah Al 'Umrayatain (dua permasalahan 'Umar). Penyebutan demikian disebabkan oleh dua buah permasalahan dalam faraidh yang dinisbahkan kepada Umar bin Khattab RA., sebagai sang penggagas ide utamanya. Sebab beliau lah orang pertama yang memutuskan dua masalah tersebut(al Ramli, n.d.).

Dua buah permasalahan itu disebut juga dengan masalah Al Gharrawain karena menyerupai bintang cemerlang oleh sebab terkenalnya, dan di sebut juga dengan istilah $A l$ Gharibatain karena asing(Al Bajuri, 2006), tak ada yang menandinginya. Dua bentuk masalah itu struktur kasus kewarisannya terdiri dari:

ADHKI: Journal of Islamic Family Law 
Kasus pertama, suami, ibu, dan bapak. Kasus kedua, istri, ibu, dan bapak(Al-Musawy, n.d.).

Adapun hukum-hukum yang berkaitan dengan dengan masalah $A l$ 'Umariyahini, adalah bahwa bagian seorang ibu dalam fardhu yang di tentukan ayat Al Qur'an ada kalanya mendapat $1 / 6$ atau $1 / 3$. Namun pada kasus istimewa ini, ibu justru mendapat bagian $1 / 4$ atau $1 / 6$, tetapi tidak dalam kondisi sebagaimana mestinya yang telah diatur dalam ketentuan ayat kewarisan(Al Tarimy, n.d.). ${ }^{4}$

Struktur kasus kewarisan istimewa/khusus dalam ilmu faraidh ditandai oleh dua hal, yaitu struktur kasusnya bersifat baku, dan ada penyimpangan dari faraidh menyangkut ketentuan bagian/hak sebagian ahli warisnya(Anwar, 1981). Kasus istimewa gharawain, merupakan salah satu contoh konkret penyelesaian harta warisan yang di dalamnya mengharuskan adanya penyelesaian pembagian warisan menurut cara-cara di luar kaidah atau ketentuan faraidh.

Dua struktur kasusnya adalah: Suami, ibu, dan ayah, atau istri, ibu, dan ayah. Pada kasus gharawain ini, ibu diistimewakan hak warisnya, yaitu dengan cara memberikan bagian tsuluts al baqi (sepertiga sisa) agar terpenuhinya konsep faraidh "dua banding satu" untuk laki-laki dan perempuan, yang dalam kasus ini adalah antara ayah dan ibu pewaris. Pada kasus kewarisan istimewa gharawain ini, lbu dan ayah sebagai pasangan gender mendapat bagian (hak) waris sebagaimana matriks berikut:

\begin{tabular}{|c|c|c|c|c|c|}
\hline \multicolumn{6}{|c|}{ Struktur Pertama Kasus Kewarisan Istimewa Gharawain } \\
\hline \multicolumn{4}{|c|}{ Penyelesaian Menurut Cara Biasa } & \multicolumn{2}{|c|}{$\begin{array}{c}\text { Penyelesaian Secara } \\
\text { Istimewa/Khusus }\end{array}$} \\
\hline No & $\begin{array}{c}\text { Ahli } \\
\text { waris }\end{array}$ & Fardh & Asal masalah $=6$ & Fardh & Asal masalah $=6$ \\
\hline 1 & Suami & $1 / 2$ & 3 & $1 / 2$ & 3 \\
\hline 2 & Ibu & $1 / 3$ & 2 & $1 / 3$ sisa & $1 / 3 \times 3=1$ \\
\hline 3 & Ayah & Ashobah & 1 & Ashobah & 2 \\
\hline \multicolumn{4}{|c|}{$\begin{array}{l}\text { Ibu mendapat dua bagian, berbanding } \\
\text { terbalik dengan ayah pewaris, padahal } \\
\text { konsep Qur'an menyatakan "li al dzakari } \\
\text { mitslu hazh al untsayain." }\end{array}$} & \multicolumn{2}{|c|}{$\begin{array}{l}\text { Ayah mendapat dua kali lipat dari } \\
\text { bagian ibu, dengan cara } \\
\text { mengistimewakan bagian ibu } \\
\text { menjadi “tsuluts al baaqi." Yaitu } \\
\text { sepertiga sisa setelah suami } \\
\text { mengambil hak/bagiannya. }\end{array}$} \\
\hline \multicolumn{6}{|c|}{ Struktur Kedua Kasus Kewarisan Istimewa Gharawain } \\
\hline \multicolumn{4}{|c|}{ Penyelesaian Menurut Cara Biasa } & \multicolumn{2}{|c|}{ Penyelesaian Secara } \\
\hline
\end{tabular}

4 Seperti: Jika pewaris ada meninggalkan keturunan (anak/cucu seterusnya ke bawah), atau karena adanya saudara yang berbilang (dua orang/lebih). 
Kasus Kewarisan Istimewa Gharawain .....

\begin{tabular}{|c|c|c|c|c|c|}
\hline & & & & & va/Khusus \\
\hline No & $\begin{array}{c}\text { Ahli } \\
\text { waris }\end{array}$ & Fardh & $\begin{array}{l}\text { Asal masalah } \\
=12\end{array}$ & Fardh & Asal masalah $=4$ \\
\hline 1 & Istri & $1 / 4$ & 3 & $1 / 4$ & 1 \\
\hline 2 & Ibu & $1 / 3$ & 4 & $1 / 3$ sisa & $1 / 3 \times 3=1$ \\
\hline 3 & Ayah & Ashobah & 5 & Ashobah & 2 \\
\hline $\begin{array}{l}\text { Ibu } \\
\text { dar } \\
\text { belt } \\
\text { bag }\end{array}$ & $\begin{array}{l}\text { nendapat } \\
\text { oada bagi } \\
\text { m menda } \\
\text { an ibu pe }\end{array}$ & $\begin{array}{l}\text { apat bagiz } \\
\text { ayah. Nas } \\
\text { dua kali } \\
\text { is. }\end{array}$ & $\begin{array}{l}\text { lebih sedikit } \\
\text { n ayah masih } \\
\text { at daripada }\end{array}$ & $\begin{array}{l}\text { Ayah men } \\
\text { bagian ibu } \\
\text { mengistim } \\
\text { menjadi “ } \\
\text { sepertiga } \\
\text { mengamb }\end{array}$ & $\begin{array}{l}\text { dua kali lipat dari } \\
\text { an cara } \\
\text { an bagian ibu } \\
\text { al baaqi."Yaitu } \\
\text { elah istri } \\
\text { bagian warisnya. }\end{array}$ \\
\hline
\end{tabular}

Atas dasar penyelesaian kasus kewarisan istimewa Gharawain ini, tampak jelas bahwa ada semacam keinginan untuk menjadikan sosok waris laki-laki itu memang harus mendapat bagian lebih banyak (dua kali lipat) dari bagian perempuan, meskipun kemudian tidak bersesuaian dengan konsekuensi ahli waris ashobah yang seharusnya mendapat bagian tidak tentu. Karena ashobah selaku ahli waris penerima sisa, hanya menunggu hasil dari pembagian warisan untuk dzawil furudh.

\begin{tabular}{|c|c|}
\hline \multicolumn{2}{|r|}{ Respon Masyarakat Terkait Kasus Gharawain/'Umrayatain } \\
\hline $\begin{array}{l}\text { Identitas } \\
\text { (Status) }\end{array}$ & Tanggapan \\
\hline MUI & $\begin{array}{l}\text { Sah-sah saja ijtihad itu untuk diterapkan atau tidak. Karena ia } \\
\text { sangat berkaitan dengan kemaslahatan dalam keluarga, dan } \\
\text { sifatnya kondisional. Dalam banyak kasus ashobah sendiri sering } \\
\text { "kebablasan." } \\
\text { Dua banding satu untuk ayah dan ibu pewaris sampai saat ini } \\
\text { masih adil gender. } \\
\text { Boleh-saja kemudian jika mau disetarakan (ishlah), tanpa } \\
\text { mengabaikan hukum pasti dari Allah Swt. Sebab furudhul } \\
\text { muqaddarah itu pasti (laisa lahu ta'wil). }\end{array}$ \\
\hline $\begin{array}{l}\text { Guru/ } \\
\text { Ustadz } \\
\text { Faraidh }\end{array}$ & $\begin{array}{l}\text { Tetap dengan ketentuan umum faraidh, meskipun bagian ayah lebih } \\
\text { sedikit karena konsekuensi ashobah. } \\
\text { Tidak masalah juga dengan bagian } 1 / 3 \text { sisa untuk ibu, karena } \\
\text { pendapat ini didukung oleh Abbas bin Abdul Muthalib. Anaknya } \\
\text { Ibnu Abbas sekalipun menolak, tetapi penolakannya ini } \\
\text { disampaikan setelah Umar ra. wafat. }\end{array}$ \\
\hline Akademisi & $\begin{array}{l}\text { Hukum asal laki-laki memang dua bagian. Jika perempuan } \\
\text { "berperan sama seperti laki-laki" maka itu kasuistik saja (bukan }\end{array}$ \\
\hline
\end{tabular}

ADHKI: Journal of Islamic Family Law 


\begin{tabular}{|c|l|}
\hline \multirow{1}{*}{ patokan). } \\
Disesuaikan proporsinya (kondisional). Bisa (2:1.1:1,1:2). \\
Tetap dengan ketentuannya, ibu 1/3 bagian bukan 1/3 sisa \\
(penghormatan kepada ibu harus lebih diutamakan). \\
Dalam arti lain, tidak bisa dibalik (konsekuensi ashobah). \\
Ijtihad Umar disepakati jumhur karena nilai kemaslahatan. \\
Adil jika dibagi sesuai proporsi dan tanggungjawab yang di pikul \\
masing-masing (ayah dan ibu pewaris).
\end{tabular}

Tanggapanpara informan ini, ketika dihubungkan dengan isu keadilan gender seperti sekarang, pada dasarnya dapat dikelompokkan pada dua varian pendapat.Pertama, kasus kewarisan istimewa ini merupakan hasil (produk) ijtihad fukaha, maka sah-sah saja untuk diterapkan atau tidak. Sebabia lebih bersifat kondisional (kasuistik). Sehingga boleh dipilih mana yang lebih memberi maslahat di tengah kasus (keluarga/ahliwaris). Kedua, Tetap berpegang dengan ketentuan umum faraidh.Sebab apa yang sudah digariskan dalam konteks ini, pada dasarnya sudah bersesuaian dengan konsep keadilan, dan senantiasa (masih) tetap adil gender.

Upaya modifikasi dalam teknis penyelesaian pembagian warisan orang yang berbeda gender dalam kasus istimewa gharawain ini, yaitu antara ibu dan ayah adalah dimaksudkan:Pertama, agar prinsip keadilan dan persamaan dapat disesuaikan seiring dengan perubahan zaman atau kondisi kekinian. Sebab konsep pembagian kewarisan dengan pola "dua banding satu" untuk laki-laki dan perempuan dalam perbedaan gender itu, oleh sebagian pendapat dipandang masih belum mencerminkan rasa keadilan secara kontekstual.

Kedua, secara logika formulasi pembagian dua banding satu untuk laki-laki dan perempuan ini, bukanlah merupakan bentuk final dari hukum kewarisan Islam. 
Sebab sebagai bagian dari hukum Islam, faraidh sendiri maqashid al syariahnya juga dmaksudkan untuk suatu tujuan mewujudkan keadilan, dan menegakkan amanah dalam masyarakat.

Konteksnya dengan persoalan isu keadilan gender dalam kasus istimewa gharawain, Syahrur dengan The Theory of Limit nya telah merumuskan, bahwa batasbatas (hudud Allah) terkait bagian laki-laki dua kali lipat perempuan itu, pada hakikatnya merupakan batas maksimal dan tidak bisa ditambah lagi, sedangkan perempuan adalah batas minimalnya. Jadi dalam konteks dan kondisi tertentu, bisa saja sebenarnya seorang perempuan memiliki hak waris (bagian) yang lebih banyak.

Jika dihadapkan dengan adanya kritik Amina Wadud terhadap model penafsiran lama yang menganggap bahwa formulasi pembagian dengan warisan dengan pola perbandingan "dua satu" untuk orang yang berbeda gender (laki-laki dan perempuan) tersebut, sebenarnya (juga) bukanlah satu-satunya rumusan yang bersifat matematis. Karena teori tersebut tidak sepenuhnya benar. ${ }^{5}$

Pendapat Amina Wadud ini tentu saja tidak bisa dipungkiri, karena memang pada kenyataannya, konsep "dua banding satu" ini hanya dikenal dalam pembahasan faraidh ketika dikaitkan dengan status dan konsekuensi ahli waris ashobah bi al ghair, dan itu pun terbatas hanya pada empat pasangan gender. ${ }^{6}$ Jadi benar seorang waris perempuan, haknya adalah seperdua dari harta warisan yang ditinggalkan pewarisnya.

Seiring dengan perubahan zaman, adanya keinginan atau pendapat lain terkait penafsiran terhadap ayat-ayat kewarisan dalam konteks perolehan ahli waris laki-laki dan perempuan di tengah isu keadilan gender seperti sekarang ini, maka pandangan (teori) Ibnu al Qayyim al Jauziahbarangkali saja bisa menjadi pertimbangan. Menurutnya bahwa begitu banyak fatwa yang sudah dikeluarkan oleh para sahabat, kalangan thabi'in, dan para mufti terkait adanya perubahan hukum ini.

Berbagai fatwa tersebut, telah memunculkan hukum yang berbeda-beda terhadap suatu pokok persoalan yang sama. Hal ini tentu saja sangat bisa dimaklumi oleh sebab adanya keragaman atau perbedaan keilmuan (bidang keahlian) dan sudut pandang (perspektif) masing-masing. Atau bahkan menyangkut adanya perubahan situasi dan kondisi, tempat, dan waktu kejadian.

Sebagai contohadalah terkait kebijakan Umar bin Khattab yang saat itu sebagai khalifah sekaligus qadli.71a dalam beberapa contoh kasus konkret kewarisan khusus ini, dan salah satu diantaranya adalah kasus kewarisan istimewa gharawain, telah menetapkan adanya konsep "dua banding satu" untuk ayah dan ibu pewaris

\footnotetext{
5Yang demikian bisa dibuktikan jika dilakukan penelitian terhadap ayat-ayat mawarits itu, maka akan ditemui bahwa rumusan "dua banding satu" untuk laki-laki dan perempuan itu, hanyalah merupakan satu diantara beberapa ragam dari model pembagian warisan untuk ahli waris yang berbeda gender ini.

6 Lihat beberapa literatur kewarisan Islam (faraidh) sebagaimana daftar pustaka (referensi) tulisan ini mengenai pembahasan tentang ahli waris ashobah bi al ghair.

7 Ia pernah memutuskan dua cara penyelesaian untuk kasus kewarisan yang sama, seperti Musytarikah/Musyarrakah, Himariyah, Hijariyah, atau Yammiyah.
}

ADHKI: Journal of Islamic Family Law 
dalam dua struktur kasus kewarisan tersebut. Padahal di sisi lain, pendapat ini secara tegas telah ditolak oleh Ibnu Abbas.

Dari berbagai teori dan perspektif, penyelesaian kasus kewarisan konkret, hendaknya tidak lagi mempertentangkan mengenai persoalan ijtihadiyah, utamanya menyangkut "keistimewaan/kekhususan" sebuah kasus kewarisan. Karena pada dasarnya, ijtihad yang sudah dihasilkan secara kompromistis, dan bahkan sudah menjadi ijma ulama ini, tentu saja sudah merupakan khazanah pemikiran yang patut dipertimbangkan. Apalagi di tengah isu keadilan gender seperti sekarang ini, respon masyarakat yang disampaikan oleh berbagai unsur seperti Majelis Ulama Indonesia, guru/ustadz faraidh, akademisi, praktisi, psikolog, dan sosiolog), terkesan sangat "adaptif."

Terbukti dengan ungkapan kalimat-kalimat yang mereka sampaikan. Seperti: "kondisional, sesuai proporsi, tidak mutlak (harus) menggunakan pola penyelesaian pembagian dengan "dua banding satu, atau satu banding dua," lebih bersifat kasuistik, ishlah/badamai, ijtihad itu bisa saja untuk diterapkan/tidak, masih adil gender..."8

Begitu juga halnya ketika dihubungkan dengan teori Syahrur; bahwa "bagian laki-laki dua kali lipat perempuan itu" merupakan batas maksimal yang tidak bisa ditambah lagi, sedangkan perempuan adalah batas minimalnya. Oleh karena itu, maka bisa jadi dalam kondisi/kasus tertentu seorang perempuan berpotensi memperoleh hak waris atau bagian yang lebih banyak. Secara faraidh, yang demikian ini dibuktikan langsung melalui kasus istimewa gharawain.

Sebab menurut Nasaruddin Umar, yang menjadi point penting dalam kewarisan Islam itu, bukanlah pada persoalan porsi yang diperoleh ahli waris perempuan. Sebab dalam konteks seperti sekarang, apakah perempuan selalu mendapatkan bagian seperduanya dari ahli waris laki-laki?, ataukah dalam praktik senyatanya, perempuan justru diberi dan mendapat hak yang sama dengan waris laki-laki. Oleh faraidh, yang demikian ini juga telah dibuktikan melalui penyelesaian kasus kewarisan khusus seperti dalam masalah Akdariyah. ${ }^{9}$

Keadilan hukum waris Islam dan kesetaraan gender dalam konteks faraidh, dijadikan sebagai solusi menghindari konflik keluarga. Sehingga kasus kewarisan istimewa/khusus ini pun jika ditinjau dari berbagai perspektif, seperti psikologis, sosiologis dan ekonomis, maka akan dapat membantah apa yang selama ini dituduhkan atau disinyalir tentang hukum waris Islam faraidh.

"ketidakadilan, ketimpangan, dan kesenjangan, atau terdapatnya semacam marjinalisasi perempuan dalam kasus kewarisan Islam, semuanya hanyalah

8 Namun semuanya tetap dalam konteks mendahulukan hukum pasti dari Allah Swt. Dalam arti lain, semua ahli waris yang ada dalam kasus-kasus kewarisan istimewa ini, semuanya sudah "menyadari" tentang furudh mereka sebagaimana yang telah ditetapkan faraidh. Sedangkan untuk masalah-masalah lainnya yang menyangkut pendapat dan pemikiran terkait keistimewaan/kekhususan kasus waris ini, mereka meresponnya lebih kepada bentuk pemikiran yang patut dipertimbangkan untuk menyesuaikan dengan contoh kasus konkret yang terjadi di masyarakat.

${ }^{9}$ Struktur kasusnya: Suami, ibu, satu orang saudara perempuan kandung, dan kakek. 


\section{Kasus Kewarisan Istimewa Gharawain .....}

merupakan isu-isu gender yang disebabkan oleh "melihat sex" dalam faraidh sebagai sebuah stereotype atau sub-ordinasi terhadap perempuan yang sesungguhnya (tidak lain) adalah mitranya laki-laki. (Wahidah, 2018, pp. 111-113)

Atas dasar ini, teori yang ditawarkan oleh Munawar Sadjali terkait perlunya dilakukan peninjauan kembali mengenai konsep "dua banding satu untuk laki-laki dan perempuan"(Sadjali, 1990) menurut peneliti tidak terlalu urgen dalam konteks keinginan untuk mereformulasikan pembagian warisan untuk mereka yang berbeda gender ini. Termasuk produk ijtihad mengenai kasus kewarisan istimewa ini di tengah isu keadilan gender seperti sekarang.

Apa yang sudah dihasilkan oleh mujtahid kenamaan melalui produk ijtihad mereka terkait penyelesaian kasus-kasus kewarisan istimewa ini, paling tidak sudah menjadi khazanah pemikiran hukum waris Islam yang telah direspon oleh banyak kalangan seperti: Majelis Ulama Indonesia, ustadz/guru faraidh, akademisi, praktisi (Hakim Pengadilan Agama), psikolog, dan sosiolog dengan pernyataan, bahwa sampai saat ini faraidh masih "adil gender."

Sebagai bagian dari hukum Islam secara keseluruhan, faraidh yang telah diatur rinci, dan sesuai dengan tujuan disyariatkannya (maqashid al syariah) hukum waris Islam ini, maka kemaslahatan, persamaan, dan keadilan bagi setiap ahli waris atas hak/perolehannya terhadap peninggalan pewarisnya, dapat dirasakan dan dibuktikan secara langsung melalui penyelesaian kasus istimewa ini secara konkret di tengah respon masyarakat yang cukup variatif.

Analisis menunjukkan, bahwa isu keadilan gender sama sekali tidak bisa dipisahkan dari pembahasan faraidh. Karena yang demikian ini sangat terkait dengan pembahasan ahli waris dari dua golongan yang berbeda gender (laki-laki dan perempuan). Selain itu maqashid al syariah secara jelas dan tegas menunjukkan bahwa keadilan, persamaan, dan maslahat menjadi bagian dari prinsip-prinsip ditetapkan hukum Islam termasuk faraidh.

Dalam banyak aspek dan perspektif, kasus istimewa gharawain pada dasarnya, bisa dipilih atau tidak untuk dijadikan sebagai solusi penyelesaian kasus pembagian harta warisan. Karena ini sangat tergantung pada kondisi dan status ibu dan ayah selaku orang tua pewaris dalam konteks kehidupan rumah tangga mereka yang masih utuh atau sudah bercerai. Ibu yang dalam hal ini akan "tertipu" dengan cara penyelesaian khusus tersebut, tentunya (sangat dimungkinkan) akan menolak diberikan bagian $1 / 3$ sisa yang "asing."

Di tengah isu keadilan gender, masyarakat merespon penyelesaian kasus kewarian istimewa gharawain ini dengan kesan yang sama sebagaimana halnya di belasan abad yang silam. Pro kontra dengan masing-masing alasan, dasar hukum sesuai profesi, keahlian dan perspektif (psikologis, sosiologis, maupun ekonomis), tetap dalam keragaman meskipun masih terkesan sangat adaptif.

Sesuai dengan tujuan disyariatkan hukum waris Islam ini, maka kemaslahatan, rasa persamaan dan keadilan bagi setiap ahli waris, khususnya dalam

ADHKI: Journal of Islamic Family Law 
dua struktur kasus bakunya ini terhadap hak atau perolehan harta warisan, samasama dapat dirasakan dan dipahami hikmahnya dari berbagai sudut pandang mana pun(Berahim, 2015).

Namun tidaklah berlebihan jika dikatakan bahwa tsuluts al baqi yang menjadi keistimewaan kasus gharawain itu, untuk tidak dijadikan sebagai bagian ketentuan (aturan) kewarisan yang bersifat mengikat nantinya(Sarmadi, 1997). Apalagi jika harus dimasukkan dalam suatu pasal khususnya ketika undang-undang waris yang dinanti-nantikan kehadirannya sudah ditetapkan.

Selain alasan perubahan hukum yang menjadi sebuah "keniscayaan," dalam konteks seperti sekarang ini, masyarakat tampaknya tidak lagi mempersoalkan masalah formulasi pembagian warisan untuk laki-laki dan perempuan yang sering disuarakan dengan istilah "dua banding satu untuk laki-laki dan perempuan." Karena dalam praktiknya masyarakat terkadang menggunakan pola-pola penyelesaian faraidh-ishlah, atau ishlah saja(Kementrian Agama RI, 2010, pp. 82-83).

Atas dasar kenyataan tersebut, pasal $178 \mathrm{KHI}$ dan pasal terkait lainnya seperti pasal 177 buku II tentang hukum kewarisan, agar dipertimbangkan kembali dalam kaitannya dengan ketentuan yang bersifat mengikat bagi para pihak (kasus ahli waris: suami, ibu, dan ayah, atau istri, ibu, dan ayah). Sebab yang demikian ini, (paling tidak) akan menghilangkan kesan bahwa "faraidh itu bias, atau tidak adil gender" dengan diadopsinya bagian $1 / 3$ sisa untuk ibu pewaris dalam dua kasus istimewanya.

Sebab versi Kompilasi Hukum Islam (KHI), hasil penyelesaian dua kasus khusus ini, menunjukkan hasil yang sama dengan apa yang sudah ada dalam ketentuan penyelesaian kasus istimewa gharawain. Belum lagi penyelesaiannya menjadi "musykil" ketika ayah pewaris diberi hak waris yang berbeda dalam dua kasusnya, yaitu 1/3 dan ashobah sebagaimana matriks berikut:

\begin{tabular}{|l|c|c|c|c|c|}
\hline \multicolumn{3}{|c|}{ Struktur Kasus Pertama } & \multicolumn{3}{c|}{ Struktur Kasus Kedua } \\
\hline Ahli Waris & Bagian & $\begin{array}{c}\text { Asal } \\
\text { Masalah } 6\end{array}$ & Ahli Waris & Bagian & $\begin{array}{c}\text { Asal } \\
\text { Masalah }\end{array}$ \\
\hline Suami & $1 / 2$ & 3 & Istri & $1 / 4$ & 1 \\
\hline Ibu & $\mathbf{1 / 3}$ sisa & $\mathbf{1 / 3} \mathbf{3} \mathbf{3} \mathbf{1}$ & Ibu & $\mathbf{1 / 3}$ sisa & $\mathbf{1 / 3}$ x 3=1 \\
\hline Ayah & $\mathbf{1 / 3}$ & $\mathbf{2}$ & Ayah & Ashobah & $\mathbf{2}$ \\
\hline $\begin{array}{l}\text { *Ayah 1/3bagian,sesuai pasal 177 KHI } \\
\text { yang dikuatkan dengan SEMA Nomor } \\
\text { 2 Taun 1994. }\end{array}$ & $\begin{array}{l}\text { Pada struktur kasus kedua ini, bagian } \\
\text { ayah, tidak disebutkan dengan bilangan } \\
\text { pecahan. Karena SEMA Nomor 2 } \\
\text { Tahun 1994 hanya mengisyaratkan } \\
\text { untuk struktur kasus pertama saja. }\end{array}$ \\
$\begin{array}{l}\text { Terkait pasal 178 point (b) tentang 1/3 sisa untuk ibu pewaris dalam dua kasus } \\
\text { istimewa versi Kompilasi Hukum Islam ini, menurut peneliti menjadi “musykil” } \\
\text { ketika dihubungkan dengan pasal 177 tentang bagian ayah pewaris. }\end{array}$ \\
\hline
\end{tabular}


Atas dasar pembahasan di atas, setiap muslim hendaknya "mewajibkan" dirinya untuk senantiasa memahami dan mendalami aspek maqashid al syariah dalam hubungannya dengan masalah kewarisan Islam ini. Sebab apa yang sudah dihasilkan fukaha di zamannya, belum tentu "sama/cocok" dengan hasil pemikiran zaman sekarang dengan banyaknya perubahan sikap atau kultur budaya hukum masyarakat.

Meskipun demikian, tetap dalam rambu-rambu pemahaman yang harus diperhatikan, bahwa "hukumkah yang harus berubah mengikuti perubahan zaman, atau zamankah yang seharusnya mengikuti hukum." Karena fikih itu senantiasa dinamis, sedangkan syariat bersifat tetap dengan kebenaran mutlak dari Yang Maha Adil dan Maha Bijaksana (sesuai firman-Nya).

\section{Kesimpulan}

Gharawain, adalah salah satu contoh kasus kewarisan istimewa/khusus dalam faraidh. Selain struktur kasusnya bersifat baku (tetap), penyelesaian pembagian harta warisannya pun, terdapat "penyimpangan" dalam konteks hak/bagian yang diterima ahli waris. Yang demikian ini, sekaligus menjadi tanda (syarat) keistimewaan bagi kasus tersebut. Tsuluts al Baqi (sepertiga sisa) dalam kasus gharawain, menjadikan ibu dalam dua kasusnya "tertipu" karena bagiannya berkurang dari $1 / 3$ menjadi $1 / 4$ atau bahkan $1 / 6$ bagian harta warisan.

Di tengah isu keadilan gender, masyarakat merespon penyelesaian kasus kewarisan istimewa gharawain ini dengan kesan yang sama seperti halnya di belasan abad yang silam. Perbedaan pendapat dengan masing-masing alasan sesuai profesi, keahlian dan perspektif, tetap dalam keragaman namun sangat adaptif.

Sesuai dengan maqashid al syariah, kemaslahatan, persamaan, dan keadilan bagi setiap ahli waris atas hak/perolehannya terhadap peninggalan pewarisnya, sama-sama dapat dirasakan dan dipahami hikmahnya dari sudut pandang manapun. Namun tidak berlebihan jika dikatakan bahwa sepertiga sisa yang menjadi keistimewaan dalam kasus gharawain itu, untuk tidak dijadikan sebagai ketentuan penyelesaian yang bersifat mengikat.

Selain alasan perubahan keadaan, praktik penyelesaian kasus-kasus kewarisan konkret di masyarakat, juga (sudah) tidak lagi mempersoalkan tentang formulasi pola pembagian "Dua banding satu untuk laki-laki dan perempuan." Terlebih lagi jika dikorelasikan dengan aspek psikologi dalam konteks ini. Ibu dan ayah pewaris, tidak bisa disetarakan kedudukan mereka dengan perbedaan gender dalam konteks ashobah bil ghair sebagaimanaketentuan faraidh.

\section{Reference}

Al-Musawy, A.-S. M. bin A. (n.d.). al Nafhat al Hasaniyyah 'ala al Tukhfat al Saniyyah fi 'Ilmi al Faraidh. Al-Haramain.

ADHKI: Journal of Islamic Family Law 
Al Bajuri. (2006). al Syaikh Ibrahim 'ala Syarh al Syansyury fi 'Ilmi al Faraidh. AlHaramain.

al Ramli, S. M. bin A. bin H. (n.d.). Nihayat al Muhtaj Ila Syarh al Minhaj fi al Fiqhi 'Ala Madzhab al Imam al Syafi'iy. Dar al Kutub al 'Ilmiyah.

Al Tarimy, M. bin S. bin H. bin A. bin al S. A. B. ibn S. al 'Alawy al H. (n.d.). Takmilat Zubdat al Hadits fi Figh al Mawarits. Al-Haramain.

Anwar, M. (1981). Faraidh Hukum waris dalam Islam dan Masalah-Masalahnya. AlIkhlas.

Basyir, A. A. (n.d.). Hukum Waris Islam. Universitas Islam Indonesia.

Berahim, A. (2015). Hukum Kewarisan Islam Solusi Menghindari Konflik Keluarga Muslim. Qiyas.

Fahmi, L. (2018). Hermeneutika Emillio Betti dan Aplikasinya dalam Menafsirkan Sistem Kewarisan 2:1 pada Surat an-Nisa Ayat 11. Ulul Albab: Jurnal Studi Dan Penelitian Hukum Islam, 2(1), 143. https://doi.org/10.30659/jua.v2i1.3120

Kementrian Agama RI. (2010). Pelaksanaan Hukum Waris di Kalangan Umat Islam Indonesia. Badan Litbang dan Diklat Puslitbang Kehidupan Keagamaan.

Muadz, F. (1994, October 21). Pengaruh Ajaran Tsulutsul Baqi dalam Kompilasi Hukum Islam. Panji Masyarakat.

Mubarak, A. (n.d.). Is'af al Raghibin fi'Ilmi al Faraidh. Ma'had al Islamy al Mursyid al Amin.

Pusvita, S. (2018). Keperdataan Anak diluar Nikah dalam Putusan Mahkamah Konstitusi dan Implikasinya terhadap Harta Warisan. Ulul Albab: Jurnal Studi Dan Penelitian Hukum Islam, 1(2), 31. https://doi.org/10.30659/jua.v1i2.2338

Sadjali, M. (1990). Islam dan Tata Negara: Ajaran, Sejarah, dan Pemikiran. UI Press.

Sarmadi, A. S. (1997). Transendensi Keadilan Hukum Waris Islam Transformatif. Raja Grafindo Persada.

Wahidah. (2018). Relasi Setara Antara Laki-laki dan Perempuan Dalam Kasus Kewarisan Islam (Faraidh). Antasari Press. 